\title{
Tracking the record of sewage discharge off Jeddah, Saudi Arabia, since 1950, using stable isotope records from antipatharians
}

\author{
Michael J. Risk ${ }^{1, *}$, Owen A. Sherwood ${ }^{2}$, Rob Nairn ${ }^{3}$, Chris Gibbons ${ }^{3}$ \\ ${ }^{1}$ PO Box 1195, Durham, Ontario N0G 1R0, Canada \\ ${ }^{2}$ Department of Earth Sciences, Memorial University of Newfoundland, St. John's, Newfoundland A1B 3X5, Canada \\ ${ }^{3}$ Baird \& Associates, Oakville, Ontario L6J 5Z7, Canada
}

\begin{abstract}
In 2007, a study was undertaken of the long-term records of the ratios of stable isotopes of carbon $\left(\delta^{13} \mathrm{C}\right)$ and nitrogen $\left(\delta^{15} \mathrm{~N}\right)$ in the skeletons of antipatharians (black corals) growing on reefs near the city of Jeddah, Saudi Arabia. Antipatharians were collected from more than 100 sites, and detailed records obtained from 31 individuals from 16 sites. Annual growth bands were identified and counted. Precision of age estimates was verified by bomb radiocarbon analyses. Some of the specimens were $>70 \mathrm{yr}$ old. Samples from a comparison reef, $15 \mathrm{~km}$ offshore in the Red Sea, showed $\delta^{15} \mathrm{~N}$ values of $4 \%$ and $\delta^{13} \mathrm{C}$ values of about $-18 \%$. The early years of growth of antipatharians from affected areas also showed $\delta^{15} \mathrm{~N}$ values of $4 \%$ and $\delta^{13} \mathrm{C}$ values of about $-18 \%$, but then in subsequent years these values changed, presumably as water quality deteriorated. Records from specimens in the harbour showed a steady increase in $\delta^{15} \mathrm{~N}$ that paralleled population growth in the city - values from 2007 frequently exceeded 8.0\%. The carbon record also showed progressive change: since 1950 , values of $\delta^{13} \mathrm{C}$ in affected areas gradually moved from about -18 to $-17 \%$. We postulate that $\delta^{15} \mathrm{~N}$ values track the input of sewage-dominated wastewater. By using correlations with species of algae that co-occur with antipatharians on outer- and mid-shelf reefs, we were able to build up a spatial and temporal picture of $60 \mathrm{yr}$ of sewage input off this coastline. The advantage of the use of bioindicators is the ability to provide baseline water quality data in places where no such data exist.
\end{abstract}

KEY WORDS: $\delta^{15} \mathrm{~N} \cdot \delta^{13} \mathrm{C} \cdot$ Sewage $\cdot \operatorname{Red~Sea} \cdot$ Antipatharians $\cdot$ Monitoring

\section{INTRODUCTION}

Increasing population density and development along the world's coastlines, coupled with limited resources or limited political will to deal with the resulting problem of waste disposal, places coastal ecosystems under increasing stress (MEA 2005). The practise of dumping sewage into the ocean is widespread: since the 1940s, the State of Florida USA, has dumped sewage onto the reefs of the east coast at a rate of 1.5 billion $1 \mathrm{~d}^{-1}$ of minimally treated sewage through 6 ocean outfall pipes. In Canada, the city of Halifax only recently installed treatment facilities, whereas Victoria, British Columbia, discharges 130 million 1 daily of raw sewage into the Strait of Juan de Fuca. In Indonesia, a country with a population of 240 million and more coral reefs than any country in the world, there are no tertiary treatment plants. The reasons why this practise is justified are: proper treatment would be expensive (which is true), there are no human health impacts (which may be true) and there are no impacts on the reefs (which is certainly untrue).

In 2007, responding to concerns about deteriorating water quality near Jeddah, a multidisciplinary study was undertaken of the waters around the city, with regard to current treatment capacity and trends in water quality. The executing agencies were Baird \& Associates, Research Planning International and Trow 
Associates. Field work was undertaken in June and July 2007. There were already reports of adverse impacts on marine ecosystems in the region, such as mangroves (Mandura 1997) and coral reefs (DeVantier \& Pilcher 2000).

One aspect of this large study was the use of the record of past water conditions recorded in the skeletons of long-lived organisms. In this regard, the skeletons of deep-water corals have shown themselves to be excellent archives of past climatic conditions. In fact, Roark et al. (2006) suggested they may be the oldest living organisms on the planet, with ages exceeding 4000 yr. A series of papers has laid out some of the techniques and insights to be gained from the study of deep-sea and shallow-water gorgonians (Sherwood et al. 2005a,b, 2009 this Theme Section, Ward-Paige et al. 2005). Black corals (antipatharians) hold immense potential because of their wide distribution and slow growth rates (Williams et al. 2006, 2007a).

Among the available analytical parameters that have proven to be extremely useful in monitoring past environments are stable isotope ratios of carbon $\left(\delta^{13} \mathrm{C}\right)$ and nitrogen $\left(\delta^{15} \mathrm{~N}\right)$. There is a large and growing body of work attesting to the ability of $\delta^{15} \mathrm{~N}$ to track sewage input in the oceans. This subject has recently been reviewed (Risk et al. 2009), and only a summary will be provided herein. The utility of the $\delta^{15} \mathrm{~N}$ technique lies in the fact that nutrients derived from animals wastes, septic systems and sewage treatments plants are enriched in $\delta^{15} \mathrm{~N}$ (Heikoop et al. 2000, Rogers 2003, Savage \& Elmgren 2004). A number of studies published over the past few years have indicated that values of $\delta^{15} \mathrm{~N}$, measured in different organisms, increase in the presence of human sewage: macroalgae from Florida (Lapointe et al. 2005) and the Ryukyu Islands (Umezawa et al. 2002); Indonesian stomatopods (Risk \& Erdmann (2000); and Jamaican corals (Mendes et al. 1997). $\delta^{15} \mathrm{~N}$ is a food-chain indicator, the values increasing with every trophic level. The utility of $\delta^{15} \mathrm{~N}$ lies in the fact that humans are the only abundant top terrestrial carnivore that dump their waste into the oceans, $\delta^{15} \mathrm{~N}$ analysis has been shown to indicate sewage stress in every study which has examined this topic and the analyses are cost-effective.

In the present study, we analysed the stable isotope ratios in the skeletons of antipatharians off the city of Jeddah to provide a $60 \mathrm{yr}$ history of sewage loading off that stretch of coastline. Because antipatharians were not found alive in close proximity to the city, we attempted to correlate antipatharian stable isotope values with other organisms such as various species of algae. We feel that the potential of antipatharians to record water quality data deserves wide dissemination, because there are many coastal locations that lack adequate baseline data on water quality.

\section{MATERIALS AND METHODS}

Study area. The port city of Jeddah, on the Red Sea coastline of Saudi Arabia (Fig. 1), is the major city of western Saudi Arabia. From its historical beginnings as a mud-walled fishing village, it has shown rapid growth. The population of the city grew from 381000 in 1971 to about 600000 in 1974 and to just over 1000000 in 1983 (Abdu et al. 2002). At present, it has a population of more than 3 million - a troubling trebling in the past $25 \mathrm{yr}$. It is the principal gateway to the holy city of Mecca, and hence has a large throughput of visitors. Only about $15 \%$ of the households are connected to municipal sewers; the rest have septic or holding tanks. There is insufficient capacity for treatment, and a portion of raw sewage discharges untreated into the coastal zone. There are 3 main outfalls; two discharge into the inner harbour quite close to each other, into the Al-Arbaeen and the Al-Shabab Lagoons, respectively; the third, Kumrah outfall, discharges well to the south of the city (Research Planning Inc. \& Baird \& Associates 2008).

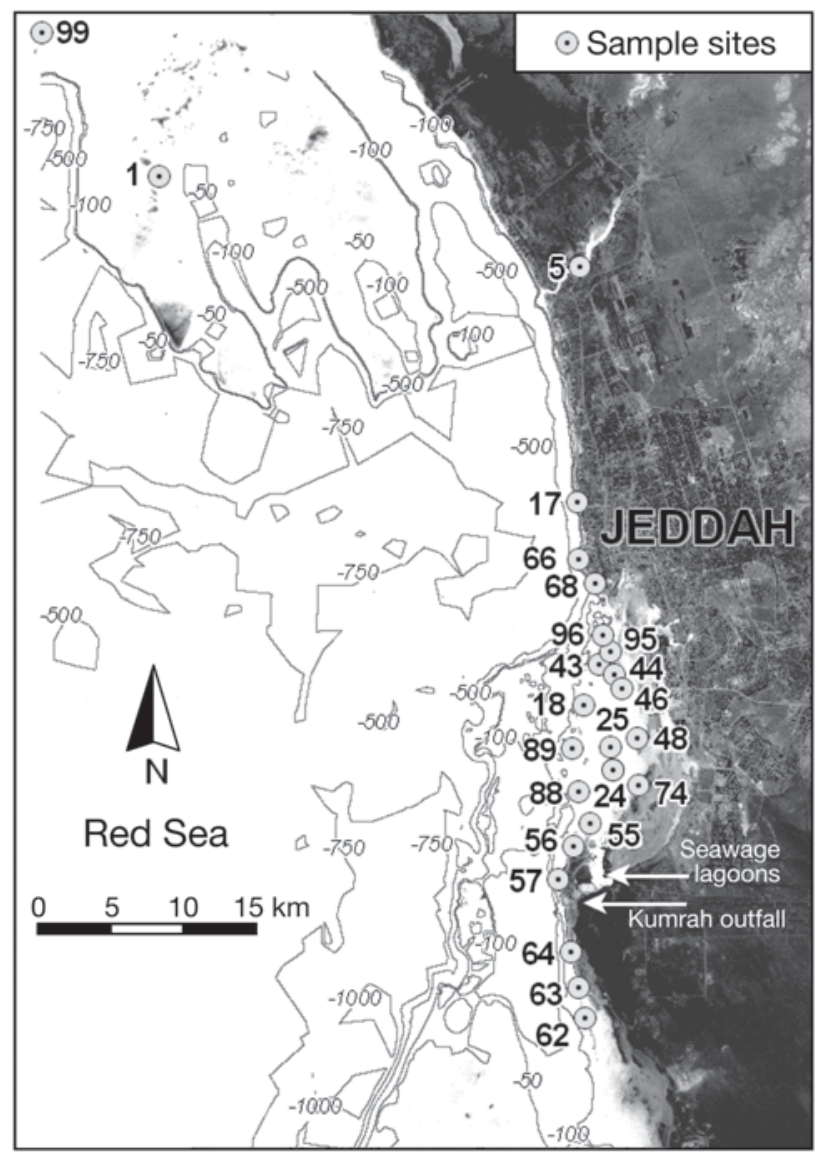

Fig. 1. Jeddah, Saudi Arabia, showing sites at which antipatharians were sampled, the Khumrah outfall and the site of the now-abandoned sewage lagoons 
There is a narrow continental shelf, on which a series of coral reefs have developed, the health of which is dependent on proximity to the city. Jeddah is a busy port, with extensive facilities. An industrial area is located southeast of the city. There are no permanent rivers or streams near the city, and essentially no terrestrial vegetation. Drinking water comes from wells and, increasingly, from desalination plants. Rare, often torrential, rainstorms activate ephemeral streams and flush sediments and refuse into the ocean.

Fieldwork. Specimens of Antipathes sp. were collected from 34 sites off Jeddah in depths ranging from 2 to $8 \mathrm{~m}$. A comparison site was selected: a patch reef about $15 \mathrm{~km}$ northeast of the city. Antipatharian samples were taken by SCUBA or snorkelling using a pair of pruning snips to cut colonies near the base. Several specimens were collected at each site, if possible. On the boat, subsamples of the base of the stem were snipped out, along with the tip, and the remainder of the colony discarded. Samples were dried, bagged and brought to Canada for analysis.

Antipatharians near the city were usually dead. In order to obtain as complete coverage of the site as possible, we attempted to intercorrelate isotopic data. We therefore co-collected antipatharians and other target species where possible (Caulerpa, Enteromorpha, seagrasses, etc.) in the hopes of developing correlations that would allow us to project isotopic trends inshore. The plan was to investigate whether tight correlations existed between antipatharians and other species at offshore sites, in which case it might be possible to project values closer to shore where antipatharians were not present.

Samples were also taken in the sewage treatment plants in the city and of the inner harbour sediments to establish levels of stable isotopes in these end members. In all, 250 samples were taken from 100 sites. Great care had to be taken when working with inner harbour sediments in order to ensure safety of operators from pathogens and pollutants.

Laboratory analysis. Growth band description and validation: Antipatharian samples were sectioned normal to the stem with a slow-speed diamond saw and then polished and photographed under a binocular microscope with ultraviolet illumination. Major (assumed annual) growth bands were counted independently by 2 experienced operators (O.A.S. and M.J.R.).

One of the largest antipatharian specimens, JED75, from $3 \mathrm{~km}$ off the central part of the port, was carefully subsampled, using the method outlined below, for accelerator mass sepctrometry(AMS) $-{ }^{14} \mathrm{C}$ dating at the Center for Accelerator Mass Spectrometry, Lawrence Livermore National Laboratory, Livermore, California, USA. The intent was to establish the level of bomb- generated ${ }^{14} \mathrm{C}$ in the sample, hence validating the visual ring counts (Sherwood et al. 2005b).

Subsampling methods: Owing to the narrow diameter $(\sim 5 \mathrm{~mm})$ of specimens, a special technique was used to obtain samples for stable isotopic and radiocarbon analysis. Briefly, 1 to $2 \mathrm{~cm}$ long pieces of skeleton, adjacent to the sections using for imaging, were sectioned longitudinally, lightly polished and triple rinsed and ultrasonically cleaned in deionised water. Halfsections were affixed to glass slides with thermoplastic glue. Slides were mounted on the moving stage of a Proxxon $^{\mathrm{TM}}$ MF70 manual micromill. Milling was performed parallel to the growth increments, starting at the margin of the skeleton and moving in towards the center in increments of $0.35 \mathrm{~mm}$. Individual samples were milled from an area measuring approximately $10 \mathrm{~mm}$ long $\times 0.5 \mathrm{~mm}$ wide $\times 0.8 \mathrm{~mm}$ deep. Powdered samples were transferred to glass vials. A subset of the specimens was sampled at higher (approximately annual) resolution using a cryotome. Here, the halfsections were trimmed or 'julienned', and frozen onto aluminum stubs with the outer margin of the skeleton facing up. The sections were then cryotomed at a resolution of $\sim 0.07 \mathrm{~mm}$.

Stable isotope analyses: Both $\delta^{13} \mathrm{C}$ and $\delta^{15} \mathrm{~N}$ were obtained from 31 specimens from 16 sites, resulting in more than 250 data points covering the past $60 \mathrm{yr}$. There were an additional 175 isotope analyses done on other organisms and sediment.

Isotopic analyses were performed by the Environmental Isotope Lab at the University of Waterloo, Canada, on a Delta Plus continuous flow-isotope ratio mass spectrometer (Thermo Finnigan) coupled to a Carlo Erba elemental analyzer (CHNS-O EA1108). The precision of analyses was $\pm 0.2 \%$ for $\delta^{13} \mathrm{C}$ and $\pm 0.3 \%$ for $\delta^{15} \mathrm{~N}$. Replicate analyses differed by less than $0.3 \%$ for $\delta^{13} \mathrm{C}$ and $0.4 \%$ for $\delta^{15} \mathrm{~N}$. The results are reported in conventional per mille notation (\%, $\pm \mathrm{SD}$ ) with $\delta^{13} \mathrm{C}$ reported as versus the PDB standard; air was the standard for $\delta^{15} \mathrm{~N}$.

\section{RESULTS}

\section{Growth rates and validation}

Visual ring counts by 2 operators were virtually identical in all cases. All specimens had pronounced annual banding when illuminated with ultraviolet light (Fig. 2). Growth rates were estimated at approximately $0.05 \mathrm{~mm} \mathrm{yr}^{-1}$. Growth rates (i.e. radius divided by number of growth rings) estimated by visual ring counts were verified with bomb- ${ }^{14} \mathrm{C}$ data obtained from specimen 75 (Fig. 3). The bomb $-{ }^{14} \mathrm{C}$ record generated from this specimen began with a $\delta^{14} \mathrm{C}$ value of $+34 \pm 4 \%$ o 
around the year 1959, increased to $+84 \pm$ $4 \%$ by 1967 and then gradually decreased to $+48 \pm 4 \%$ by 2003 , overlapping with 2 reference chronologies from the Red Sea (Cember 1989). The oldest specimen we retrieved was 81 yr old when sampled.

\section{Stable isotope trends}

Most of the antipatharians records exhibit similar patterns, and only those records considered significant or illustrative are discussed herein. All data are available in the supplement at www.intres.com/articles/suppl/m397p219_app/.

Algae and sediments obtained from the bottom of the Al-Arbaeen Lagoon, a few metres from the discharge pipes of 2 of the sewage plants, had average $\delta^{15} \mathrm{~N}$ values of $13.3 \pm 1.04 \%(n=4)$ and $\delta^{13} \mathrm{C}$ values of $-15.0 \pm 0.73 \%$ o $(n=4)$.

At the offshore comparison site, 5 separate antipatharian specimens were analysed, with records dating back to 1950

(Fig. 4). During the $60 \mathrm{yr}$ of record, values of $\delta^{15} \mathrm{~N}$ in the 2 older specimens decreased somewhat, but from about 1980 onwards were stable, at $4 \%$. During this same time period, values of $\delta^{13} \mathrm{C}$ dropped somewhat, from -17 to $-18.5 \%$.

Further antipatharians results are grouped by site (Figs. $5 \& 6$ ). Fig. 5 reproduces the average values of both $\delta^{15} \mathrm{~N}$ and $\delta^{13} \mathrm{C}$ from a series of sites to the north of Jeddah, Sites 4, 5, 8, 46 and 75. Fig. 6 shows the average $\delta^{15} \mathrm{~N}$ and $\delta^{13} \mathrm{C}$ values from a series of sites nearer to and to the south of the harbour.

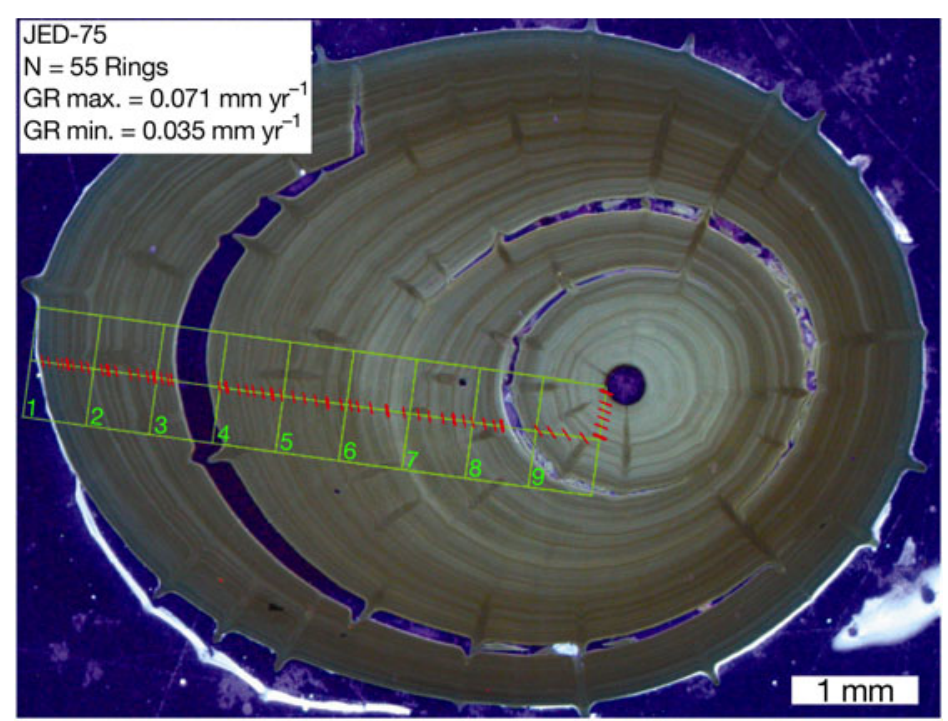

Fig. 2. Antipathes sp. Cross-section of antipatharian from Site 75, showing annual growth bands and average growth rates (GR)
Sites 4 and 5 were located in an inlet up the coast from Jeddah, called the Sharm Obhur, used as a recreational resource. Residences line the sides, and weekend boat traffic is high. The outer part of the Sharm connects with the open sea. The specimen from Site 4 showed an elevation of about $1 \%$ in $\delta^{15} \mathrm{~N}$, from 4 to $5 \%$, beginning in about 1980 . Values of $\delta^{13} \mathrm{C}$ were relatively steady at -16 to $-17 \%$ until the turn of the 20 th century, when they dropped $1 \%$ o to $-18 \%$. The picture from Site 5, about $2 \mathrm{~km}$ from the open sea, is somewhat different. Four specimens were analysed from this site. From 1940 until the present, levels of $\delta^{15} \mathrm{~N}$ remained steady, ranging from 4 to $5 \%$, with a final (2007) average of $4.2 \%$. The $4 \delta^{13} \mathrm{C}$ traces all show the same trend - a steady drop since 1940 from $-16 \%$ o to present levels of $-18 \%$.

Site $8 \mathrm{~b}$ was located between the Sharm Obhur and the harbour, off a stretch of coastline with a large number of hotels. Construction of these hotels involved dewatering of the sites by pumping groundwater to the sea. At this site, all 3 replicates showed the same trends in $\delta^{15} \mathrm{~N}$ and $\delta^{13} \mathrm{C}$ : a gradual increase of about $1 \%$ o since 1950 in $\delta^{15} \mathrm{~N}$ to modern levels of $6.0 \%$, and a drop in $\delta^{13} \mathrm{C}$ over the same period of time from -17 to $-18.5 \%$.

Moving down into the area of the harbour, and the direct influence of the city, the antipatharian records all showed the same trend: increasing levels of $\delta^{15} \mathrm{~N}$ from 1950 to the present, as well as moderate decreases in 
the $\delta^{13} \mathrm{C}$ record. Site 46 was located off the central part of the harbour, a little over $2 \mathrm{~km}$ offshore. The record shows that in 1960, levels of $\delta^{15} \mathrm{~N}$ were about the same as at the offshore comparison site, about $4.5 \%$. There was a steady rise to values between 6 and $7 \%$ in the 1990s, and the record has stayed level since. The $\delta^{13} \mathrm{C}$ record from this site is relatively steady, at values a bit below $-17 \%$.

One of the longest records we have comes from Site 75 , just south of the naval facilities and only $2 \mathrm{~km}$ off-
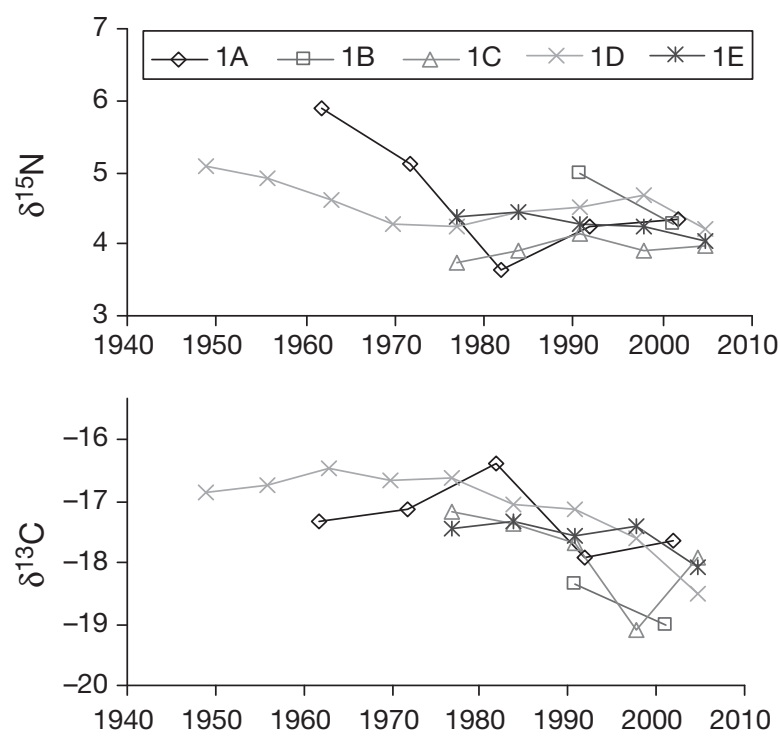

Fig. 4. $\delta^{15} \mathrm{~N}$ and $\delta^{13} \mathrm{C}$ values from replicate samples of Antipathes $\mathrm{sp}$. from the comparison reef, Site 1, $15 \mathrm{~km}$ offshore Jeddah
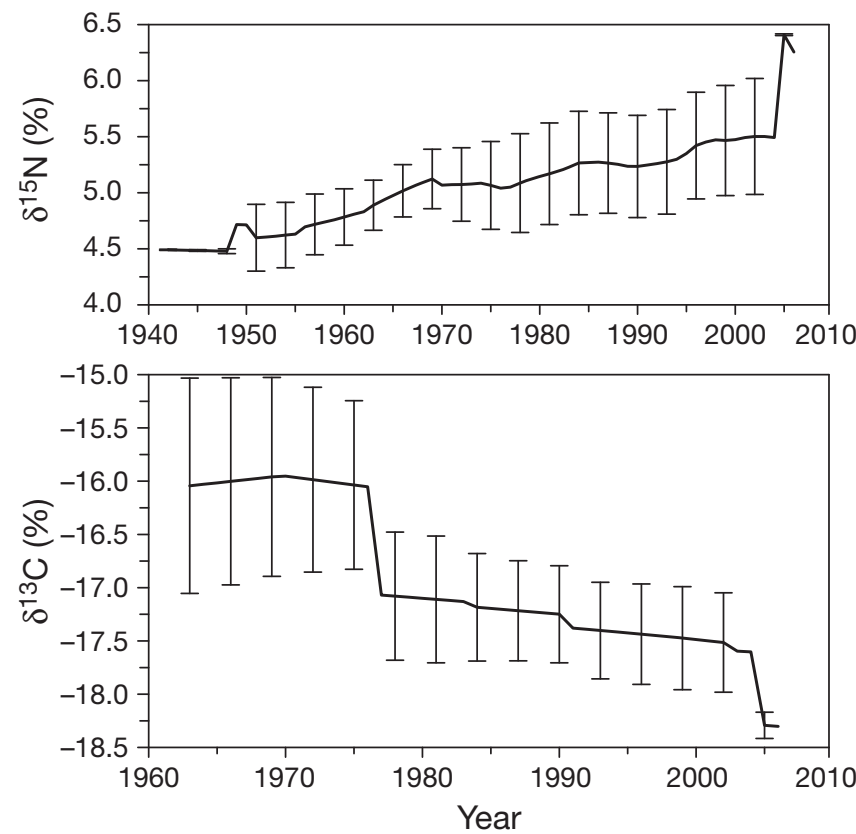

Fig. 5. Composite of values of $\delta^{15} \mathrm{~N}$ and $\delta^{13} \mathrm{C}$ in antipatharians from Sites 4, 5, 8, 46 and 75. Error bars are $\pm 1 \mathrm{SD}$
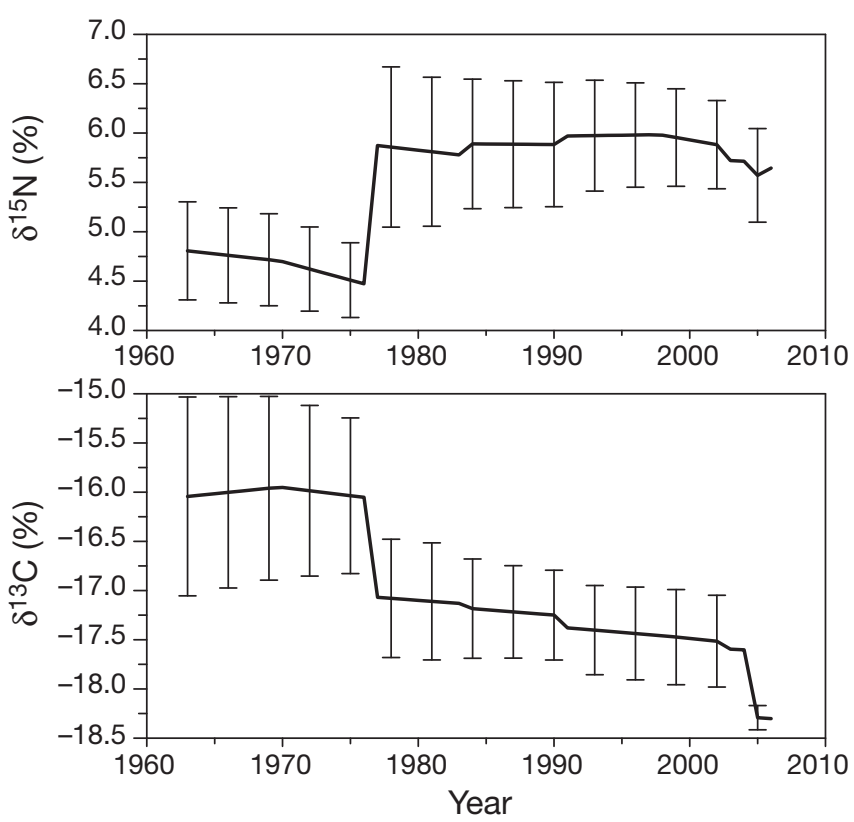

Fig. 6. Composite of values of $\delta^{15} \mathrm{~N}$ and $\delta^{13} \mathrm{C}$ in antipatharians from Sites 57, 60, 62, 63, 85 and 88. Error bars are $\pm 1 \mathrm{SD}$

shore. The $\delta^{15} \mathrm{~N}$ record began before 1950 with values of $4 \%$, the same as those for the comparison site. Then they began a steady rise to present values of 7 . The $\delta^{13} \mathrm{C}$ record showed a slow drop of $1 \%$ from -17.5 to $-18.5 \%$ over the same period of time.

Site 85 was less than $2 \mathrm{~km}$ from shore, directly off the port and down-drift from the major discharges from Jeddah. Only one small antipatharian was found alive at this site, and hence the record is not very long. Nonetheless, the sample recorded the highest $\delta^{15} \mathrm{~N}$ value encountered in any antipatharian in the present study, $8.39 \%$. The value has been virtually stable since about 1980, indicating that there has been at least $30 \mathrm{yr}$ of sewage discharge at the site. The $\delta^{13} \mathrm{C}$ record from this site ranged between -17 and $-18 \%$.

Site 88 was almost $10 \mathrm{~km}$ offshore from Site 75. This is a small specimen with a short record, but nonetheless indicates that even $10 \mathrm{~km}$ from shore the sewage signal is still very high. The sample was too small to allow trends to be established, but the $\delta^{15} \mathrm{~N}$ signal was between 6 and $7 \%$, while the $\delta^{13} \mathrm{C}$ signal remained constant at $-18 \%$.

Site 57 was just offshore and slightly north of the large Kumrah outfall, near the large, shallow sewage lagoons. The specimen was quite small and so the record is short. Nonetheless, it showed very high $\delta^{15} \mathrm{~N}$ values (between 6 and $7.3 \%$ ), as well as a slight drop in the $\delta^{13} \mathrm{C}$ record, from -17 to $-18 \%$ o during the period 1985-2005.

Sites 60, 62 and 63 (Fig. 6) each recorded different aspects of the impact of the Kumrah outfall $\left(200000 \mathrm{~m}^{3}\right.$ discharge $\mathrm{d}^{-1}$ ). Site 63 was the closest, about $3 \mathrm{~km}$ south of the outfall, and quite close to shore in an area 
where the currents set north-south. It may not be exposed to the full discharge. Site 62 was located $2 \mathrm{~km}$ further south and $1 \mathrm{~km}$ further out to sea. Finally, Site 60 was well south and almost $3 \mathrm{~km}$ offshore.

At Site 63, records from 2 specimens showed that the $\delta^{15} \mathrm{~N}$ values have been essentially constant at $5 \%$ since 1970. There was a small offset in the $\delta^{13} \mathrm{C}$ records from the 2 specimens, about $1 \%$, but those values have also essentially remained constant at $-18 \%$. At Site $62, \delta^{15} \mathrm{~N}$ values were constant and high, 6\%, from 1970 to the present, and the carbon record was also essentially unchanged, at $-18 \%$.

The picture at Site 60 is somewhat different from the 2 sites along the coast to the north. At Site 60 , the $\delta^{15} \mathrm{~N}$ values were constant at $4 \%$, the same as values recorded from the comparison site, until the mid1980 s, when the Khumrah outfall opened. The $\delta^{15} \mathrm{~N}$ record from this site began to climb in the mid-1980s, reaching a final value of $5.4 \%$.

A complete listing of the isotopic data obtained in this study, including data not discussed herein due to space limitations, is provided at www.int-res.com/articles/ suppl/m397p219_app/. Also provided is an animation of the data set, showing the change in values of $\delta^{15} \mathrm{~N}$ over the past $60 \mathrm{yr}$ in the waters offshore Jeddah.

\section{DISCUSSION}

One of the first things to note about this data set is the fidelity of the record. Bomb $-{ }^{14} \mathrm{C}$ dating shows that the error of visual counts of annual growth bands is quite small, even as far back as the 1950s. Most of the age determinations in the present study on which the trends are based are therefore accurate to a degree that may be matched only by a few other proxies. In addition, fidelity among specimens from the same sites is excellent. At every site where several specimens were analysed, the differences among the records was rarely more than $1 \%$, and the overall trends were always parallel. Similar levels of intercolony reproducibility have been documented with other species of proteinaceous corals from other regions (Sherwood et al. 2005b, 2009, this Theme Section, Williams et al. 2007a). We are therefore confident that the records from these antipatharians faithfully record the history of sewage input to these coastal waters, as measured using $\delta^{15} \mathrm{~N}$ as a proxy, covering the period 1955-2007. We believe this is the first time a study of this sort has ever been attempted.

These data suggest that, in the period 1950-1970, the sea off Jeddah likely was a healthy ecosystem. Values of $\delta^{15} \mathrm{~N}$ in the antipatharians were at the same levels as offshore comparison sites are today, and healthy coral reefs flourished near the city (A. Kotob pers. comm.).
In the early 1970s, the health of the system, as measured by $\delta^{15} \mathrm{~N}$, began to decline. Increases at most sites were monotonic, leading to present antipatharian values often in excess of $8.0 \%$. A picture of the present situation, even into the inner harbour, can be produced by using correlations with other organisms. If tight correlations could be established between antipatharians and other organisms co-occurring at the same site, then values established from the co-occurring organism could be used when antipatharians were not present, e.g. because they died off close to the city. After early reconnaissance, we chose to analyse Enteromorpha, Sargas-

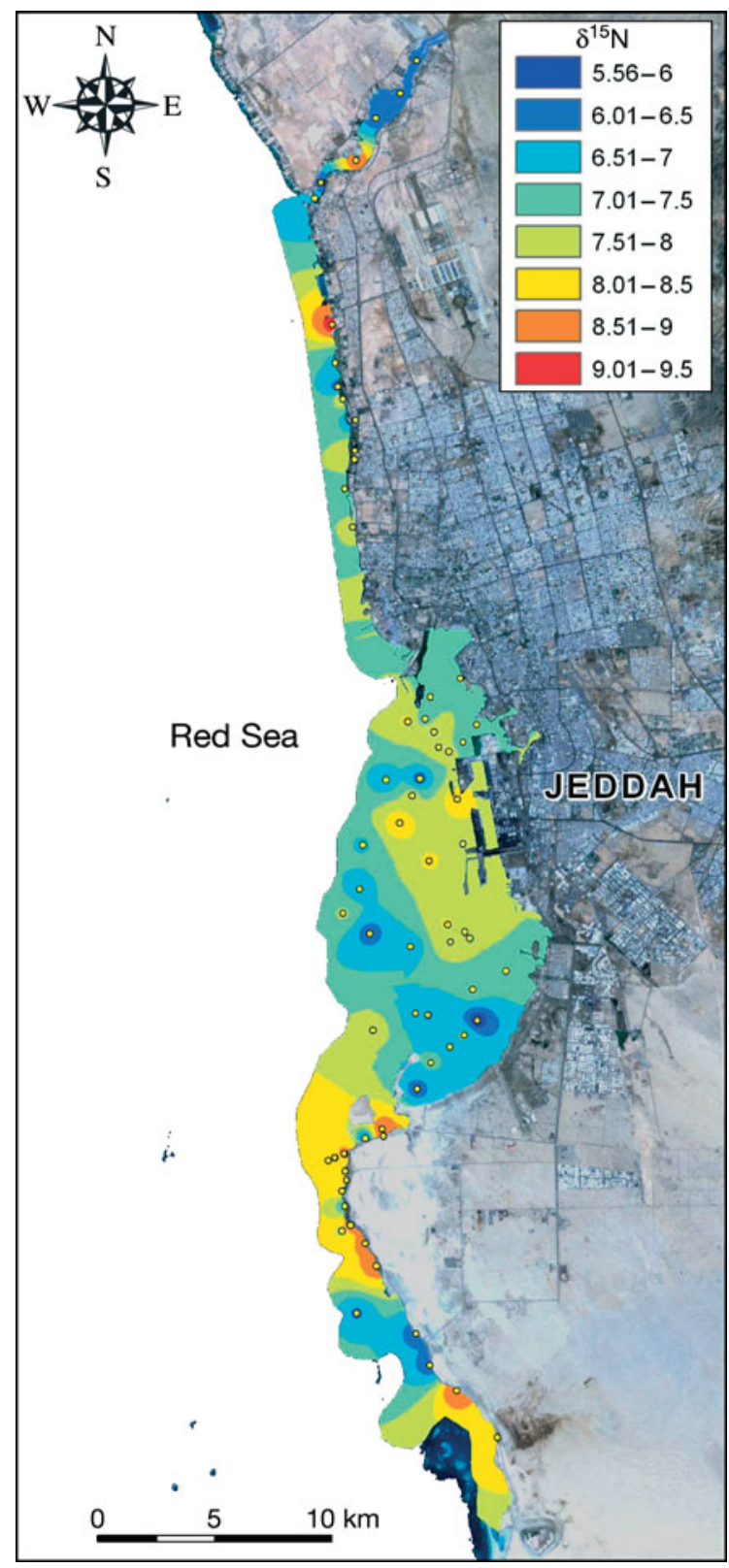

Fig. 7. Normalised SI Antipathes sp. $\delta^{15} \mathrm{~N}$ values, at present, along the Jeddah coastline. 
sum, Turbinaria, Caulerpa and sediments, where they could be found together with antipatharians.

Although we feel this technique has great potential, this aspect of the present study proved to be extraordinarily difficult both in the sampling and interpretation phases. First of all, it was very difficult to find at least 2 of the organisms at each site; therefore, sample size was low. Second, correlations were often weak. This is perhaps not surprising, since isotopic ratios in algae will change during the course of the year in ways which are as yet unknown to us. For this technique to work well, either the isotopic ratios of the partner organisms will not exhibit pronounced variations with time or season, or their annual fluctuations will have to have been established in advance.

Some of the correlations between stable isotope values of antipatharians and other organisms were disappointing. The correlation with Enteromorpha had high variance. The correlation with Turbinaria was reasonable $\left(\mathrm{r}^{2}=0.51, \mathrm{n}=5, \mathrm{p}=0.18\right)$, and we decided to use this correlation to project the isotope data shorewards into the harbour. The result (Fig. 7) is a picture of present-day water quality, offshore to onshore. In a few nearshore, highly contaminated areas where antipatharians were not found, and where Turbinaria were collected, we have used the antipatharian-Turbinaria correlation to produce equivalent antipatharian values. These have been termed 'normalised' values.

A comparison of the water quality pictures derived from antipatharian and algal $\delta^{15} \mathrm{~N}$ values with those developed from major water quality parameters, such as phosphate, nitrate, chlorophyll $a$, etc., indicates that the pictures are broadly comparable. In short, the stable isotope values in the chosen bioindicators provide cost-effective data that are a useful addition to the usual multi-parameter array of water quality measurements.

The picture to the south of Jeddah is complicated. Dumping of sewage on those flats reportedly ceased about $10 \mathrm{yr}$ ago. The drop in $\delta^{15} \mathrm{~N}$ at the site could simply signify a decrease in sewage input and a return to more normal marine conditions (less sewage-stressed conditions). On the other hand, we observed bacterial and cyanobacterial mats growing in those sewage lagoons. It is possible that these were $\mathrm{N}$-fixing bacteria, which utilize atmospheric $\mathrm{N}$ and hence have a signal of close to zero. The decrease in $\delta^{15} \mathrm{~N}$ values at this site could then reflect the admixture of sources - low from the N-fixing bacteria, high from the sewage.
The increase in $\delta^{15} \mathrm{~N}$ values since 1980 at Site 60 , to the south of Khumrah, again could reflect the opening of the Khumrah outfall in the mid-1980s. Sewage-derived material could have been brought to Site 60 by the prevailing winds and currents, which are to the south.

Although Jeddah sits at the edge of one of the globe's great deserts, it does rain (rarely). There was no recorded rain from 1945 until 1996, and then a series of (for the area) significant rainfalls began, with $200 \mathrm{~mm}$ recorded in 1997. Fig. 8 shows the cumulative rainfall, as recorded near the south channel draining into the harbour, plotted against the long antipatharian record from Site 75. The values of $\delta^{15} \mathrm{~N}$ begin to increase immediately after the rains, suggesting that the rainfall acted to flush additional sewage into the harbour, which has been recorded in the antipatharians' skeletons.

Information may also be gained by examining the $\delta^{13} \mathrm{C}$ records, although that was not the focus of the present study. Although some of the $\delta^{13} \mathrm{C}$ records remain essentially unchanged from 1950 to the present, most of them show a steady decrease of about $1 \%$, accelerating over the past 20 yr. Part of this change may be attributed to the oceanic Suess effect, in which surface waters of the world have become gradually depleted in $\delta^{13} \mathrm{C}$ from the uptake of isotopically depleted anthropogenic $\mathrm{CO}_{2}$. Similar patterns of decreasing $\delta^{13} \mathrm{C}$ have been measured in antipatharian and gorgonian corals from the Northwest Atlantic (Sherwood et al. 2005b, Williams et al. 2007a) and Northeast Pacific (Williams et al. 2007b). Sediment cores recovered from the Gulf of Aqaba showed a decrease of $0.63 \%$ in the $\delta^{13} \mathrm{C}$ of planktonic foraminifera over the past $200 \mathrm{yr}$ (Al-Rousan et al. 2004).

As there was essentially no terrestrial signal at Jeddah in the mid-20th century - no runoff, no freshwater

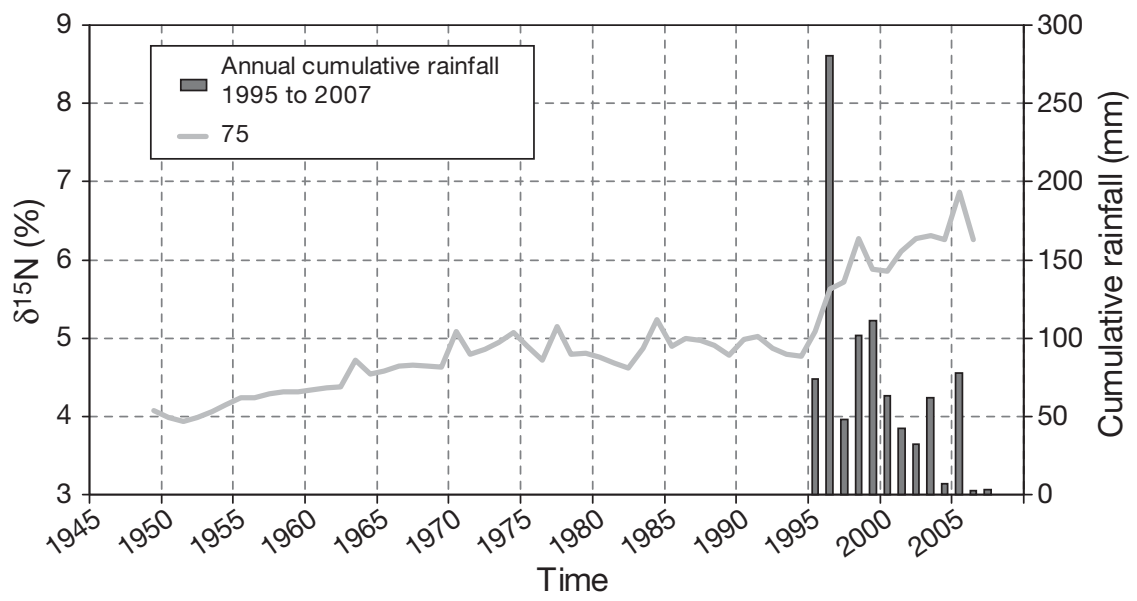

Fig. 8. Time-series of values of $\delta^{15} \mathrm{~N}$ in the skeleton of an Antipathes specimen from Site 75 , off the main part of the harbour, versus annual cumulative rainfall records for Jeddah. Note that there was no rain from 1950 until 1996; the rains that came in 1996 flushed material into the harbour, where it was picked up by the coral 
input, no terrestrial vegetation - the initial $\delta^{13} \mathrm{C}$ signals observed, about $-17 \%$, represent the marine plankton signal in the Red Sea near Jeddah. Lorian et al. (1992) measured $\delta^{13} \mathrm{C}$ values of roughly $-21 \%$ for open-sea plankton from the Gulf of Eilat. Assuming the diet of the antipatharians would be largely zooplankton plus adsorbed organic matter, a value of $-18 \%$ would be expected, considerably different from what was observed. The shift to heavier (less negative) values in the last 20 yr may reflect changes in the nature of the output from the city.

\section{CONCLUSIONS}

(1) Stable isotope records from the skeletons of antipatharians provide high-quality data, replicable among specimens from the same sites and spanning the life of the organism (in this case, more than $60 \mathrm{yr}$ ).

(2) Water quality off Jeddah has deteriorated, especially in the last $30 \mathrm{yr}$. Levels of $\delta^{15} \mathrm{~N}$ in antipatharian skeletons have increased by more than $4 \%$ since 1950 , and in comparison with specimens from offshore comparison areas, from 4 to $>8 \%$.

(3) At sites within the influence of the city, there has been a gradual decrease in $\delta^{13} \mathrm{C}$ in antipatharian skeletons, from about -18 to $-17 \%$. As there is essentially no terrestrial input at this site, this change in $\delta^{13} \mathrm{C}$ probably represents increasing utilisation of imported terrestrial material in the diets of the inhabitants.

(4) In areas with insufficient baseline data, analysis of the records encoded in the skeletons of long-lived organisms can provide useful data.

Acknowledgements. This work was funded by a contract between the Kingdom of Saudi Arabia Presidency for Meteorology and the Environment (PME), Research Planning International Inc. (RPI) and Baird \& Associates. M.J.R. thanks the Saudi commercial divers who helped with the sampling, especially 'Jeff', who died the week after we left. L. Cotsapas and T. Montello of RPI assisted in the fieldwork and data interpretation. Replicate samples of antipatharians and other organisms are archived with M.J.R.

\section{LITERATURE CITED}

Abdu MS, Salagoor JY, Al-Harigi FA (2002) Jeddah urban growth and development process: the underlying factors. Sci J King Faisal Univ 3:111-136

Al-Rousan S, Patzold J, Al-Moghrabi S, Wefer G (2004) Invasion of anthropogenic $\mathrm{CO}_{2}$ recorded in planktonic foraminifera from the northern Gulf of Aqaba. Int J Earth Sci 93:1066-1076

Cember R (1989) Bomb radiocarbon in the Red Sea: a medium-scale gas exchange experiment. J Geophys Res C 94:2111-2123

Heikoop JM, Risk MJ, Lazier AV, Edinger EN and others (2000) Nitrogen-15 signals of anthropogenic nutrient loading in reef corals. Mar Pollut Bull 40:628-636

DeVantier L, Pilcher NJ (2000) Status of coral reefs in Saudi Arabia: 2000. PERSGA Technical Series Report, Jeddah
Lapointe BE, Barile PJ, Littler MM, Littler DS (2005) Macroalgal blooms on southeast Florida coral reefs: II. Cross-shelf discrimination of nitrogen sources indicates widespread assimilation of sewage nitrogen. Harmful Algae 4:1106-1122

Lorian D, Erez J, Lazar B (1992) Stable carbon isotopes in the reef ecosystem of the Gulf of Eilat, Red Sea. In: Richmond RH (ed) Proc 7th Int Coral Reef Symp. University of Guam, Mangilao, p 364

Mandura AS (1997) A mangrove stand under sewage pollution stress: Red Sea. Mangroves Salt Marshes 1:255-262

Mendes JM, Risk MJ, Schwarcz HP, Woodley JD (1997) Stable isotopes of nitrogen as measures of marine pollution: a preliminary assay of coral tissue from Jamaica. Proc 8th Int Coral Reef Symp 2:1869-1872

Millennium Ecosystem Assessment (MEA) (2005) Ecosystems and human well-being: wetlands and water synthesis. World Resources Institute, Washington, DC

Research Planning Inc. and, Baird \& Associates (2008) Jeddah coastal assessment. Report prepared for the Presidency of Meteorology and the Environment. Kingdom of Saudi Arabia Presidency of Meteorology and Environment

Risk MJ, Erdmann MV (2000) Isotopic composition of nitrogen in stomatopod (Crustacea) tissues as an indicator of human sewage impacts on Indonesian coral reefs. Mar Pollut Bull 40:50-58

Risk MJ, Lapointe BE, Sherwood OA, Bedford BJ (2009) The use of $\delta^{15} \mathrm{~N}$ in assessing sewage stress on coral reefs. Mar Pollut Bull 58:793-802

> Roark EB, Guilderson TP, Dunbar RB, Ingram BL (2006) Radiocarbon-based ages and growth rates of Hawaiian deep-sea corals. Mar Ecol Prog Ser 327:1-14

Rogers KM (2003) Stable carbon and nitrogen isotope values indicate recovery of marine biota from sewage pollution at Moa Point, New Zealand. Mar Pollut Bull 46:821-827

Savage C, Elmgren R (2004) Macroalgal (Fucus vesiculosis) $\delta^{15} \mathrm{~N}$ values trace decrease in sewage influence. Ecol Appl 14:517-526

Sherwood OA, Scott DB, Risk MJ, Guilderson TP (2005a) Radiocarbon evidence for annual growth rings in the deep-sea octocoral Primnoa resedaeformis. Mar Ecol Prog Ser 301:129-134

Sherwood OA, Heikoop JM, Scott DB, Risk MJ, Guilderson TP, McKinney RA (2005b) Stable isotopic composition of deep-sea gorgonian corals Primnoa spp.: a new archive of surface processes. Mar Ecol Prog Ser 301:135-148

Sherwood OA, Thresher RE, Fallon SJ, Davies DM, Trull TW (2009) Multi-century time-series of ${ }^{15} \mathrm{~N}$ and ${ }^{14} \mathrm{C}$ in bamboo corals from deep Tasmanian seamounts: evidence for stable oceanographic conditions. Mar Ecol Prog Ser 397: 209-218

Umezawa Y, Miyajima T, Yamamuro M, Kayanne H, Koike I (2002) Fine-scale mapping of land-derived nitrogen in coral reefs by $\delta^{15} \mathrm{~N}$ in macroalgae. Limnol Oceanogr 47:1405-1416

Ward-Paige CA, Risk MJ, Sherwood OA (2005) Reconstruction of nitrogen sources on coral reefs: $\delta^{15} \mathrm{~N}$ and $\delta^{13} \mathrm{C}$ in gorgonians from Florida Reef Tract. Mar Ecol Prog Ser 296:155-163

Williams B, Risk MJ, Ross Sw, Sulak KJ (2006) Deep-water antipatharians: proxies of environmental change. Geology 34:773-776

Williams B, Risk MJ, Ross SW, Sulak KJ (2007a) Stable isotope data from deep-water antipatharians: 400-year records from the southeastern coast of the United States of America. Bull Mar Sci 81:437-447

Williams B, Risk MJ, Stone R, Sinclair D, Ghaleb B (2007b) Oceanographic changes in the North Pacific Ocean over the past century recorded in deep-water gorgonian corals. Mar Ecol Prog Ser 335:85-94 